\title{
Stimulation of Activin A Expression in Rat Aortic Smooth Muscle Cells by Thrombin and Angiotensin II Correlates with Neointimal Formation In Vivo
}

\author{
John E. Pawlowski, ${ }^{\star}$ David S. Taylor, ${ }^{\star}$ Maria Valentine,, Mark E. Hail,, Patricia Ferrer, ${ }^{\star}$ Mark C. Kowala, \\ and Christopher J. Molloy* \\ *Cardiovascular Drug Discovery and ${ }^{\ddagger}$ Analytical Research and Development, Bristol-Myers Squibb Pharmaceutical Research Institute, \\ Princeton, New Jersey 08543
}

\begin{abstract}
Vasoactive GTP-binding protein-coupled receptor agonists (e.g., angiotensin II [AII] and $\alpha$-thrombin) stimulate the production of mitogenic factors from vascular smooth muscle cells. In experiments to identify mitogens secreted from AII- or $\alpha$-thrombin-stimulated rat aortic smooth muscle (RASM) cells, neutralizing antibodies directed against several growth factors (e.g., PDGF and basic fibroblast growth factor [basic FGF]) failed to inhibit the mitogenic activity of conditioned media samples derived from the cells. In this report, we found that polyclonal neutralizing antibodies directed against purified human placental basic FGF reduced the mitogenic activity of AII-stimulated RASM cell-conditioned media and in immunoblot experiments identified a $26-\mathrm{kD}$ protein (14 $\mathrm{kD}$ under reducing conditions) that was distinct from basic FGF. After purification from RASM cell-conditioned medium, amino acid sequence analysis identified the protein as activin A, a member of the TGF- $\beta$ superfamily. Increased activin A expression was observed after treatment of the RASM cells with AII, $\alpha$-thrombin, and the protein kinase $\mathrm{C}$ agonist PMA. In contrast, PDGF$\mathrm{BB}$ or serum caused only a minor induction of this protein. Although activin A alone only weakly stimulated RASM cell DNA synthesis, it demonstrated a potent comitogenic effect in combination with either EGF or heparin-binding EGF-like growth factor in the RASM cells, increasing DNA synthesis by up to fourfold. Furthermore, in a rat carotid injury model, activin A mRNA was upregulated within $6 \mathrm{~h}$ after injury followed by increases in immunoreactive protein detected in the expanding neointima 7 and $14 \mathrm{~d}$ later. Taken together, these results indicate that activin $\mathrm{A}$ is a vascular smooth muscle cell-derived factor induced by vasoactive agonists that may, either alone or in combination with other vascular derived growth factors, have a role in neointimal formation after arterial injury. (J. Clin. Invest. 1997. 100: 639-648.) Key words: atherosclerosis • restenosis • remodeling $\cdot$ EGF $•$ TGF- $\beta$
\end{abstract}

Address correspondence to Christopher J. Molloy, Ph.D., CV Drug Discovery, K13-09, Bristol-Myers Squibb PRI, P.O. Box 4000, Princeton, NJ 08543. Phone: 609-252-4292; FAX: 609-252-6964; E-mail: molloy@ bms.com J.E. Pawlowski's present address is Amgen Boulder, Inc., Boulder, CO 80301.

Received for publication 11 October 1996 and accepted in revised form 24 April 1997.

J. Clin. Invest.

(c) The American Society for Clinical Investigation, Inc. 0021-9738/97/08/0639/10 \$2.00

Volume 100, Number 3, August 1997, 639-648

http://www.jci.org

\section{Introduction}

Vascular smooth muscle cell proliferation and extracellular matrix production are important components of arterial remodeling in the vascular diseases of atherosclerosis, hypertension, and restenosis after percutaneous transluminal coronary angioplasty (PTCA). ${ }^{1}$ Although the key molecules involved in these processes are not known, several vasoactive agonists including angiotensin II (AII) and $\alpha$-thrombin have been implicated. These G-protein-coupled receptor (GPCR) agonists are potent mitogens for rat aortic smooth muscle (RASM) cells in vitro (1-6) and also induce extracellular matrix formation (7-10). AII acts by direct activation of the AII type 1 $\left(\mathrm{AT}_{1}\right)$ receptor $(11)$, whereas $\alpha$-thrombin binds to its receptor and by enzymatic cleavage, generates a new amino terminus tethered ligand that activates the receptor (for review see reference 12). Early intracellular signaling events in RASM cells in response to AII and $\alpha$-thrombin include increased levels of intracellular $\mathrm{Ca}^{2+}$, phosphoinositide turnover and formation of diacylglycerol $(13,14)$. AII and $\alpha$-thrombin also stimulate signaling events associated with cellular proliferation including protein tyrosine phosphorylation, activation of the Raf-1/mitogen-activated protein kinase pathway, and nuclear proto-oncogene expression (e.g., c-myc, c-fos, and c-jun, for review see references 15 and 16).

Many of the mitogenic signaling events activated by AII and $\alpha$-thrombin are shared with growth factor agonists of tyrosine kinase receptors, including PDGF. However, the mitogenic responses to AII or $\alpha$-thrombin in vascular smooth muscle cells are delayed when compared with PDGF-BB $(17,18)$. This delay may be because of the autocrine production of growth factors secreted from the RASM cells in response to the GPCR agonists, rather than a direct mitogenic effect of the GPCR agonists. In this regard, AII and $\alpha$-thrombin have been shown to stimulate the expression of PDGF-A chain (19-21), basic fibroblast growth factor (FGF) $(22,23)$, IGF-1 (24), and as yet unidentified mitogens (18) which may be responsible ultimately for the mitogenic effects of these GPCR agonists.

Smooth muscle cell proliferation in response to AII and $\alpha$-thrombin has been implicated in the pathology of postPTCA restenosis in animal models. However, in various human clinical trials, angiotensin-converting enzyme (ACE) inhibitors or thrombin inhibitors have failed to demonstrate a decrease in post-PTCA restenosis $(25,26)$. The therapeutic failures of these agents in treating restenosis may be a result of redundant signaling by other GPCR agonists, including endothelin-1 $(3,18)$. Therefore, a rational approach for interven-

1. Abbreviations used in this paper: AII, angiotensin II; FGF; fibroblast growth factor; GPCR, G-protein-coupled receptor; HB-EGF, heparin-binding EGF-like growth factor: PTCA, percutaneous transluminal coronary angioplasty; RASM, rat aortic smooth muscle; SFDME, serum-free DME. 
tion in post-PTCA restenosis may be to inhibit the common autocrine factor(s) secreted from vascular smooth muscle cells in response to various GPCR agonists, rather than the individual agonists alone.

In previous studies characterizing the mitogenic factors secreted from RASM cells in response to AII or $\alpha$-thrombin, we have used neutralizing antibodies raised against basic FGF and PDGF and found that these growth factors do not significantly contribute to the secreted mitogenic activity (18). In this report, we have identified a specific lot of polyclonal antibodies raised against purified human placental basic FGF that inhibited the mitogenic activity present in the conditioned media of RASM cells stimulated with either AII or $\alpha$-thrombin. In immunoblotting experiments of RASM cell-conditioned media samples performed under reducing conditions, these antibodies identified a 14-kD protein, distinct from basic FGF, which was purified and identified as activin A. In addition, we describe the mitogenic activity of activin A toward vascular smooth muscle cells and the regulation of activin A expression in vitro by vasoactive agonists and in vivo in response to carotid artery injury.

\section{Methods}

Cell culture. Primary RASM cells used in this study expressed smooth muscle $\alpha$-actin, $\mathrm{AT}_{1}$ receptors, and osteopontin, all markers for the neointimal vascular smooth muscle phenotype $(18,27)$. All cells were routinely screened for mycoplasma contamination before use. RASM cells were grown in DME supplemented with $4,500 \mathrm{mg} / \mathrm{l}$ D-glucose, L-glutamine and $25 \mathrm{mM}$ Hepes containing $10 \% \mathrm{vol} / \mathrm{vol}$ FBS, $100 \mathrm{U} / \mathrm{ml}$ penicillin, and $100 \mu \mathrm{g} / \mathrm{ml}$ streptomycin. Cells were passaged at $80-90 \%$ confluence with $0.25 \%$ trypsin and were used between passages 12 and 20. For the collection of conditioned media for protein purification, cells were grown in 10-layer Cell Factories (Nunc, Inc., Naperville, IL) containing 1 liter of media. Swiss 3T3 mouse fibroblasts were obtained from American Type Culture Collection (Rockville, MD). Fibroblasts were maintained in DME plus $10 \%$ calf serum and antibiotics. FBS was obtained from Hyclone (Logan, UT). Transferrin and fibronectin were from Collaborative Biomedical Products (Bedford, MA). All other cell culture reagents were obtained from GIBCO-BRL (Gaithersburg, MD) unless otherwise specified.

Growth factors, antibodies, and other reagents. Recombinant human heparin-binding EGF-like growth factor (HB-EGF), PDGF-BB, and TGF- $\beta_{1}$, as well as murine EGF, were purchased from R \& D Systems (Minneapolis, MN). Human $\alpha$-thrombin (3072 NIH U/mg) was obtained from Enzyme Research Laboratories (South Bend, IN). AII was purchased from Peninsula Laboratories Inc. (Belmont, CA). PMA was purchased from Sigma Chemical Co. (St. Louis, MO). Polyclonal anti-basic FGF antibodies (lot 921221, AD921221; lot 930826, AD930826) were obtained from American Diagnostica Inc. (Greenwich, CT). These antibodies were confirmed to inhibit $\left[{ }^{3} \mathrm{H}\right]$ thymidine incorporation induced by recombinant basic FGF in either fibroblasts or RASM cells. Monoclonal anti- $\alpha$-inhibin/activin subunit antibody was purchased from Biodesign International (Kennebunk, ME). Recombinant human activin A (lot 15365-36[1]) and follistatin (lot B3904) were generously provided by the National Hormone and Pituitary Program (National Institute of Diabetes and Digestive and Kidney Diseases, the National Institute of Child Health and Human Development and the U.S. Department of Agriculture). $\left[{ }^{125} \mathrm{I}\right]$ Protein A $(30 \mathrm{mCi} / \mathrm{mg})$ was obtained from Amersham and [methyl- ${ }^{3} \mathrm{H}$ ] thymidine $(50-90 \mathrm{Ci} / \mathrm{mmol})$ was purchased from DuPont NEN (Boston, MA).

Liquid chromatography/electrospray ionization mass spectrometry. A sample containing $\sim 200$ picomol of activin dimer in $300 \mu \mathrm{l}$ of
$25 \mathrm{mM}$ Tris-HCl, $\mathrm{pH}$ 8.7/200 mM NaCl/0.1\% CHAPS (Sigma Chemical Co.) was acidified with $1 \mu \mathrm{l}$ of neat trifluoroacetic acid, autoinjected onto a protein trap column ( $1 \mathrm{~mm} \times 10 \mathrm{~mm}$ PLRP-s 4,000 $\AA$ ) using an Alcott 738R refrigerated autosampler and washed with $\mathrm{H}_{2} \mathrm{O}$ / acetonitrile/acetic acid (78:20:2) to remove the nonvolatile salt, buffer, and detergent. During injection, the trap column was switched in line and samples were separated on a $0.5 \mathrm{~mm}$ i.d. $\times 50 \mathrm{~mm}$ PLRP-s $4,000 \AA$ column. A gradient from $20-95 \%$ solvent $\mathrm{B}$ in $20 \mathrm{~min}$ at a flow rate of $20 \mu \mathrm{l} / \mathrm{min}$ was used. Solvent A contained $\mathrm{H}_{2} \mathrm{O}$ /acetonitrile/acetic acid (96:2:2) and B contained acetonitrile/n-propanol/ $\mathrm{H}_{2} \mathrm{O}$ /acetic acid (78:10:10:2). Gradients were formed using a microHPLC system from Michrom BioResources (Auburn, CA). Mass spectrometry was conducted using a Finnigan MAT TSQ 7000 (San Jose, CA) equipped with an electrospray ionization source. The instrument was scanned from $\mathrm{m} / \mathrm{z} 600-2,400$ in $5 \mathrm{~s}$ using the first quadrupole in the profile data acquisition mode and positive ion detection.

Mitogenic and antibody neutralization assays. RASM cells $(5 \times$ $10^{4}$ cells per well) were plated on fibronectin coated 24-well Primaria (Becton Dickinson Labware, Lincoln Park, NJ) tissue culture plates. After $48 \mathrm{~h}$, the cells were rinsed twice with PBS and rendered quiescent by incubating for $72 \mathrm{~h}$ in serum-free DME supplemented with $10 \mathrm{nM}$ selenium sulfite, $5 \mu \mathrm{g}$ transferrin per milliliter, $100 \mathrm{U} / \mathrm{ml}$ penicillin, and $100 \mu \mathrm{g} / \mathrm{ml}$ streptomycin (SF-DME). In some experiments, insulin $(2 \mu \mathrm{g} / \mathrm{ml})$ was also included. The cells were then incubated for $24 \mathrm{~h}$ with either fresh SF-DME, 10\% FBS, or conditioned media samples from AII or $\alpha$-thrombin stimulated RASM cells. $\left[{ }^{3} \mathrm{H}\right]$ Thymidine $(10 \mu \mathrm{Ci} / \mathrm{ml})$ was added for the last $6 \mathrm{~h}$ of the assay. In assays in which activin A and follistatin were incubated with RASM cells for 24 or $48 \mathrm{~h}$, $\left[{ }^{3} \mathrm{H}\right]$ thymidine was added at the beginning of the assay. For assays of recombinant activin A on fibroblasts, Swiss 3 T3 cells were plated as described then serum-starved for $18 \mathrm{~h}$ in SF-DME supplemented with insulin $(2 \mu \mathrm{g} / \mathrm{ml})$ and BSA $(0.1 \%)$. Test factors were added and the cells were incubated for $16 \mathrm{~h}$ followed by pulse-labeling with $\left[{ }^{3} \mathrm{H}\right]$ thymidine for an additional $6 \mathrm{~h} .\left[{ }^{3} \mathrm{H}\right]$ thymidine incorporation in all experiments was measured by liquid scintillation spectrometry after precipitation with ice-cold $5 \% \mathrm{wt} / \mathrm{vol}$ trichloroacetic acid and solubilization at $37^{\circ} \mathrm{C}$ in $0.25 \mathrm{~N} \mathrm{NaOH}$. For antibody neutralization assays, conditioned media samples were pre-incubated with antibasic FGF antibodies $(25 \mu \mathrm{g} / \mathrm{ml})$ at $37^{\circ} \mathrm{C}$ for $1 \mathrm{~h}$ before adding to cells.

Collection of RASM cell conditioned media. Confluent cultures of RASM cells were growth arrested by incubation for $48 \mathrm{~h}$ in SFDME. Cells were then either unstimulated or stimulated with $1 \mu \mathrm{M}$ AII, $10 \mathrm{nM} \alpha$-thrombin, $20 \mathrm{ng} / \mathrm{ml}$ PDGF-BB, or $200 \mathrm{nM}$ PMA in SFDME. The conditioned media was collected and aliquots were snap frozen and stored at $-80^{\circ} \mathrm{C}$. Before freezing, CHAPS was added to a final concentration of $0.1 \%$ to the conditioned media samples used for protein purification.

Purification of activin A from AII-stimulated RASM cell-conditioned media. Quiescent RASM cells were stimulated with AII in SFDME without transferrin for $8 \mathrm{~h}$ and the conditioned media (20 liters) was collected. Aliquots were concentrated 20-fold using an Amicon stirred cell (Model 8400; Amicon, Inc., Beverly, MA) fitted with a YM10 membrane. Aliquots were pooled and the buffer was adjusted to $25 \mathrm{mM}$ Tris- $\mathrm{HCl}, \mathrm{pH} 7.8$, containing $0.1 \%$ CHAPS by diafiltration. The sample was loaded onto a Macro-Prep High $\mathrm{Q}$ anion exchange column (Bio-Rad Laboratories, Hercules, CA) and the flow-through was collected. The flow-through was adjusted to $25 \mathrm{mM}$ Tris- $\mathrm{HCl}, \mathrm{pH} 8.7$ plus $0.1 \%$ CHAPS by diafiltration and reapplied to the Macro-Prep High Q column equilibrated in the same buffer. The column was eluted with a linear gradient of $0-1 \mathrm{M} \mathrm{NaCl}$ in the equilibration buffer and fractions were monitored for proteins that were immunoreactive with the antibasic FGF antibody (AD921221). For amino acid sequence analysis, $\sim 400$ picomol of the purified fraction was electrophoresed under nonreducing conditions on a $10-27 \%$ SDS-PAGE gel which was prerun with $100 \mathrm{mM}$ sodium thioglycolate. The gel was stained with Coomassie Brilliant Blue R-250 and dried. The dried gel was submitted to the Microsequencing and Mass Spec- 
trometry Core Facility at the Beckman Research Institute of the City of Hope, Duarte, CA, for Edman sequence analysis after in-gel trypsin digestion.

SDS-PAGE and immunoblot analysis. Conditioned media samples from unstimulated or agonist stimulated RASM cells were concentrated using Centricon-10 concentrators (Amicon Inc.) and aliquots representing $1 \mathrm{ml}$ of unconcentrated conditioned media were analyzed by SDS-PAGE and immunoblot analysis as described previously (28). Gels run under nonreducing conditions were soaked in $5 \%$ mercaptoethanol in electrophoretic transfer buffer before electroblotting onto PVDF membranes (Immobilon; Millipore Corp., Bedford, MA). Immunoreactive proteins were visualized using $\left[{ }^{125} \mathrm{I}\right]$ protein A, followed by autoradiography.

RNA extraction and Northern blot analysis. Confluent cultures of RASM cells were made quiescent by incubation in SF-DME for $72 \mathrm{~h}$ and were stimulated with $1 \mu \mathrm{M}$ AII for various times. RNA was isolated from the cells using the Quick-Prep mRNA Purification Kit (Pharmacia LKB, Piscataway, NJ) according to the manufacturer's instructions. In carotid injury studies (see below), total RNA was obtained from whole rat carotids (five per treatment group) as described previously (29). Samples of either poly A ${ }^{+}$RNA (2.5 $\mu \mathrm{g}$ per lane) or total RNA (7.5 $\mu \mathrm{g}$ per lane) were electrophoretically resolved in formaldehyde-denaturing gels and transferred to Nytran nylon membranes (Schleicher \& Schuell, Inc., Keene, NH). The activin probe corresponded to the full-length coding region $(30,31)$ and was generated by reverse transcription-PCR (RT-PCR) using poly $\mathrm{A}^{+}$ RNA isolated from RASM cells stimulated with $1 \mu \mathrm{M}$ AII. The oligonucleotide 5'-ATGCGAATTCCAGGATGCCCTTGCTTTGGCTGAGA-3' was used as the forward primer and the oligonucleotide 5'-GCGCTCTAGAGACACCC-TAGATCCATTTGCT-3' was used as the reverse primer. The resulting cDNA insert was subcloned into the plasmid pcDNA3 (Invitrogen, Carlsbad, CA) and verified by sequencing. For Northern analyses, the cDNA insert was excised from the plasmid using EcoRI and $\mathrm{XbaI}$ and $\left[{ }^{32} \mathrm{P}\right]$ labeled by random priming using the Redi-Prime system (Amersham Corp., Arlington Heights, IL). Blots were hybridized overnight at $42^{\circ} \mathrm{C}$ in $5 \times \mathrm{SSPE} / 50$ $\mathrm{mM}$ Tris- $\mathrm{HCl}, \mathrm{pH} 7.6 / 2 \times$ Denhardt's solution $/ 40 \%$ formamide $/ 10 \%$ dextran sulfate $/ 1 \%$ SDS, and $100 \mathrm{mg} / \mathrm{ml}$ sheared herring testes DNA
$(1 \times \mathrm{SSPE}=150 \mathrm{mM} \mathrm{NaCl}, 10 \mathrm{mM}$ sodium phosphate, and $1 \mathrm{mM}$ EDTA). After hybridization, blots were rinsed in $2 \times \mathrm{SSPE} / 0.1 \%$ SDS at $42^{\circ} \mathrm{C}$ followed by $0.2 \times \mathrm{SSPE} / 0.1 \%$ SDS at $42^{\circ} \mathrm{C}$.

Rat carotid injury model. Normotensive male Sprague Dawley rats (Taconic Farms Inc., Germantown, NY), 11-12 wk of age (350$400 \mathrm{~g}$ ) at the time of surgery, were handled in accordance with the guidelines of the Bristol-Myers Squibb Animal Care and Use Committee. On the day of surgery, rats were anesthetized intraperitoneally with ketamine hydrochloride $(70-80 \mathrm{mg} / \mathrm{kg}$ ) and xylazine hydrochloride $(8-10 \mathrm{mg} / \mathrm{kg}$ ) and the neck was prepared for aseptic surgery as described previously (32). Briefly, the bifurcation of the common carotid artery was exposed and a $2 \mathrm{~F}$ Fogarty arterial balloon catheter was inserted into the left external carotid artery, passed through the common carotid artery, and advanced into the aortic arch. The balloon was inflated and slowly pulled through the carotid artery to the bifurcation. The balloon was deflated and the procedure repeated three more times to insure complete removal of the endothelium. After the fourth pass, the left external carotid artery was ligated, the neck wound was closed, and the animals were allowed to recover on heating mats overnight before being returned to their cages. For RNA analysis, the animals were killed at either 6 h, 7 d, or $14 \mathrm{~d}$ after the balloon catheter injury, and the carotid arteries were perfused in situ with cold PBS, and the injured as well as contralateral uninjured carotid arteries were excised and snap frozen in liquid nitrogen.

Immunohistochemistry. Animals were necropsied at either 2, 4, 7, or $14 \mathrm{~d}$ after balloon injury. The carotid arteries were dissected and $7-\mu \mathrm{m}$ thick sections from each specimen were cut, deparaffinized, and rehydrated with distilled deionized water. Sections then were incubated with either a murine anti-smooth muscle $\alpha$-actin monoclonal antibody (BioGenex Labs, San Ramon, CA), or murine anti-activin $\beta$ A monoclonal antibody (Biodesign International, Kennebunk, ME) for $1 \mathrm{~h}$. Nonimmune mouse serum and buffer controls were also run for each time point examined. The sections were incubated with a goat anti-mouse secondary antibody (BioGenex Labs) for $30 \mathrm{~min}$. An alkaline phosphatase streptavidin-conjugated enzyme complex (BioGenex Labs), or a horseradish peroxidase streptavidin-conjugated enzyme complex (BioGenex Labs) was then applied to sections

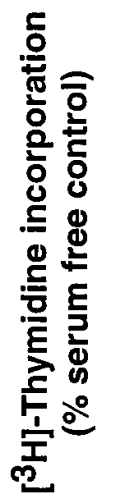

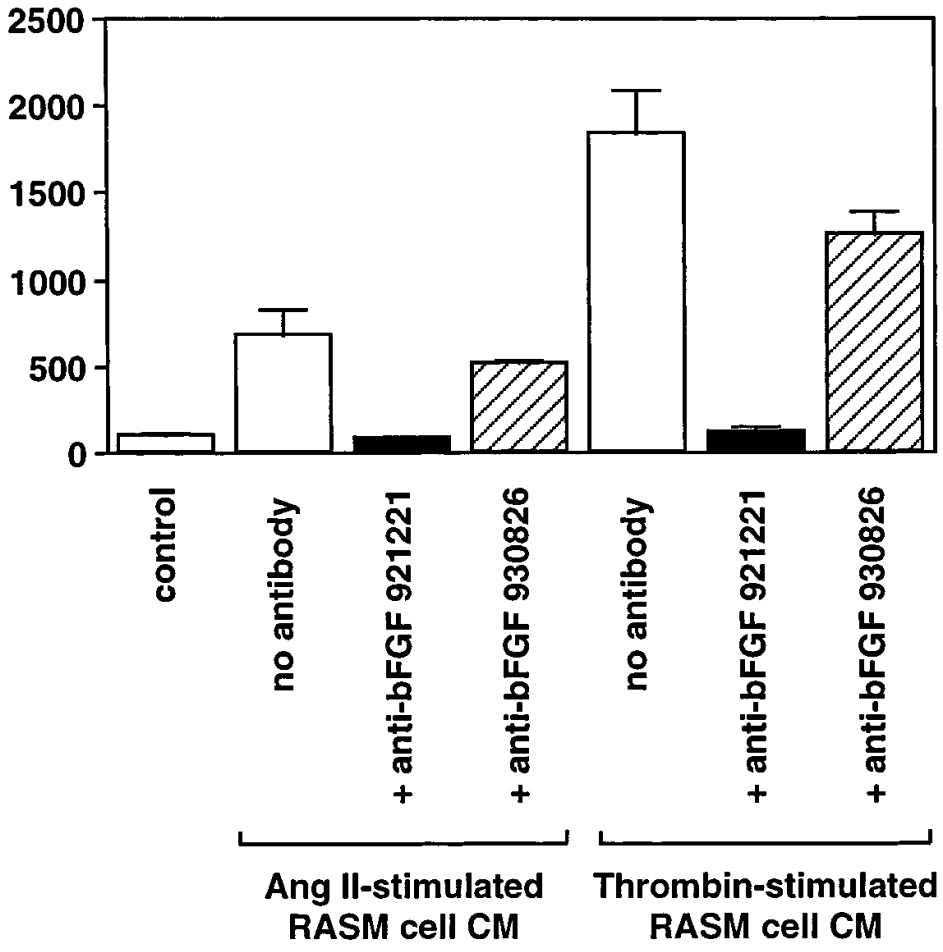

Figure 1. Specific basic FGF-neutralizing polyclonal antibodies inhibit the mitogenic effects of RASM cell conditioned media samples. Quiescent RASM cells were treated with conditioned media $(C M)$ samples obtained from RASM cells stimulated previously with AII or $\alpha$-thrombin. Before stimulation of the reporter cells, the CM samples were either untreated (open bars) or preincubated for $1 \mathrm{~h}$ with the neutralizing antibasic FGF antibodies AD921221 (solid bars) or AD 930826 (hatched bars). Relative $\left[{ }^{3} \mathrm{H}\right]$ thymidine incorporation was determined after $24 \mathrm{~h}$ (see Methods). Results are expressed as a percentage of the serum free control levels and represent the mean \pm SD of three treatment wells from a representative experiment performed three times. 
stained for $\alpha$-actin and activin A, respectively. Antismooth muscle $\alpha$-actin antibody staining was visualized using an alkaline phosphatase fast blue chromogen substrate (Zymed Labs, Inc., South San Francisco, CA). Antiactivin $\beta A$ antibody was identified using the horseradish peroxidase chromogen AEC (Biomeda Corp., Foster City, CA), yielding a red color. Slides were mounted with an aqueous mounting medium and overlaid with a glass coverslip. Double antibody detection was achieved by performing the $\alpha$-actin immunolabeling procedure before the activin A detection procedure. Since the $\alpha$-actin stained blue and the activin A stained red, colocalization of smooth muscle $\alpha$-actin and activin A produced a purple color.

\section{Results}

Neutralization of a mitogenic activity present in conditioned media samples obtained from either AII- or $\alpha$-thrombin-stimulated RASM cells using antibodies directed against purified placental basic FGF. In previous studies, we demonstrated that AII or $\alpha$-thrombin stimulation of quiescent RASM cells induced the secretion of a potent mitogenic activity within 3-6 h (17, $18)$. In the present report, mitogenic conditioned media samples derived from cells stimulated with either AII or $\alpha$-thrombin were treated with polyclonal antibodies raised against chromatographically-purified basic FGF from human placenta, AD921221 (Fig. 1). This specific antibody preparation blocked the mitogenic activity of RASM conditioned media when assayed on serum-starved RASM cells (Fig. 1). This led to initial speculation that basic FGF might be responsible for the mitogenic activity secreted from RASM cells in response to AII and $\alpha$-thrombin. However, we confirmed that basic FGF was not the principal RASM cell-secreted mitogen since a different lot of the antibody, AD930826, raised against a similar antigen and obtained from the same supplier, demonstrated only a slight decrease in the mitogenic activity (Fig. 1). Furthermore, in our previous studies, potent monoclonal basic FGF-neutralizing antibodies also failed to inhibit the mitogenic activity of conditioned media obtained from RASM cells stimulated with either $\alpha$-thrombin (Pawlowski, J.E., unpublished results) (18) or AII (17). Taken together, these results exclude basic FGF as a significant secreted mitogen from the agonist-stimulated RASM cells.

Identification of an antibasic FGF AD921221 immunoreactive protein in conditioned media from AII-stimulated RASM cells. Conditioned media samples were obtained from quiescent RASM cells that were either untreated or stimulated with AII for $8 \mathrm{~h}$. After concentration, the samples were analyzed by immunoblotting using antibasic FGF AD921221 antibodies. As shown in Fig. 2, under reducing conditions a $M_{r}=14 \mathrm{kD}$ protein was detected in conditioned media samples from AIIstimulated RASM cells that was not observed in the control conditioned media samples (Fig. 2, compare lanes 1 and 2). Under nonreducing conditions this protein was resolved at $M_{r}$ $\sim 26 \mathrm{kD}$ (Fig. 2, lane 5). This protein was not identified by a different lot of antibasic FGF antibodies, AD930826 (data not shown), and was distinct from recombinant basic FGF which migrated at $\mathrm{M}_{\mathrm{r}} \sim 18 \mathrm{kD}$ in both reducing and nonreducing gels (Fig. 2, lanes 3 and 6). In related experiments, we were unable to detect significant expression of this antibasic FGF AD921221 immunoreactive protein in conditioned media samples obtained from proliferating RASM cells or quiescent cells stimulated with FBS (data not shown).

Identification of the $\beta A$ chain of inhibin (activin $\beta A$ ) in AII-
123
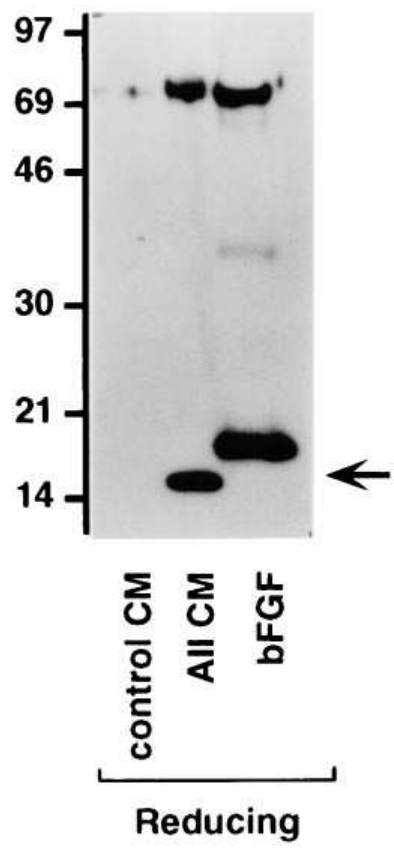

456
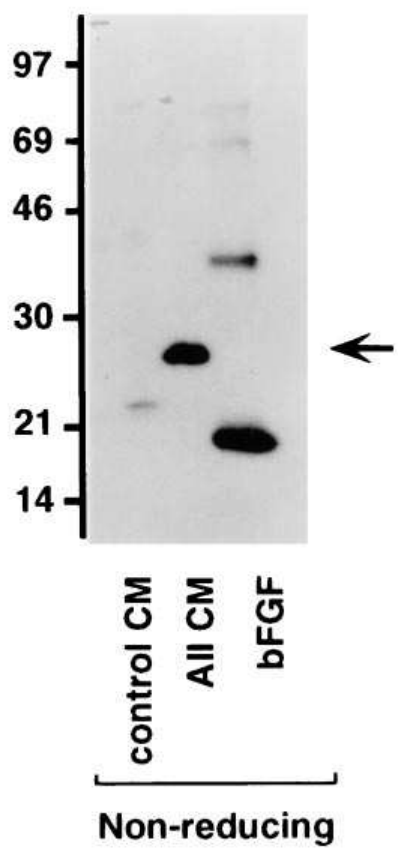

Figure 2. Immunoblot detection of a protein secreted by AII-stimulated RASM cells using an antibody that neutralizes the mitogenic activity of the conditioned medium. Quiescent RASM cells were either unstimulated (lanes 1 and 4 ) or stimulated with AII $(1 \mu \mathrm{M})$ for $8 \mathrm{~h}$ (lanes 2 and 5). Conditioned media samples were concentrated and analyzed by SDS-PAGE and immunoblot analysis. Samples were immunoblotted with antibasic FGF AD921221 $(10 \mu \mathrm{g} / \mathrm{ml})$ and immunoreactive proteins were visualized using $\left[{ }^{125} \mathrm{I}\right]$ protein A. Lanes 3 and 6 contain purified basic FGF (50 ng per lane) as a positive control for the antibody. Lanes 1,2, and 3 were run under reducing conditions and lanes 4,5, and 6 were run under nonreducing conditions. Arrow, immunoreactive protein in AII-stimulated RASM conditioned media samples.

stimulated RASM cell conditioned medium and confirmation of the dimer complex subunit composition by mass spectroscopy. Conditioned media samples from AII-stimulated RASM cells were concentrated and subjected to anion exchange chromatography. The antibasic FGF AD921221 immunoreactive fractions were purified to near homogeneity. Approximately 400 picomol of protein was electrophoresed under nonreducing conditions and the protein band corresponding to the immunoreactive protein was subjected to in-gel trypsin digestion. Recovered peptides were analyzed by Edman sequencing and yielded the sequences $\mathrm{NH}_{3}$-Tyr-Tyr-Asp-Asp-Gly-Gln-Asn$\mathrm{CO}_{2} \mathrm{H}$ and $\mathrm{NH}_{3}-$ Met-Leu-Tyr-Tyr-Asp-Asp- $\mathrm{CO}_{2} \mathrm{H}$. A search of the Swiss-Prot database revealed that these peptides demonstrated $100 \%$ amino acid sequence identity with the $\beta$ A subunit of inhibin.

The inhibins are polypeptide dimers consisting of an $\alpha$-subunit which is disulfide-linked to either a $\beta A$ or $\beta B$ subunit (for reviews see references 33 and 34). Activins, on the other hand, correspond to the related $\beta$ chain dimers. Thus, activin $A, B$, and $\mathrm{AB}$, correspond to $\beta \mathrm{A} \beta \mathrm{A}-, \beta \mathrm{B} \beta \mathrm{B}$-homodimers, or $\beta \mathrm{A} \beta \mathrm{B}$ heterodimers of inhibin, respectively. The purified protein was determined to be one of the subtypes of activin, since the mo- 
A
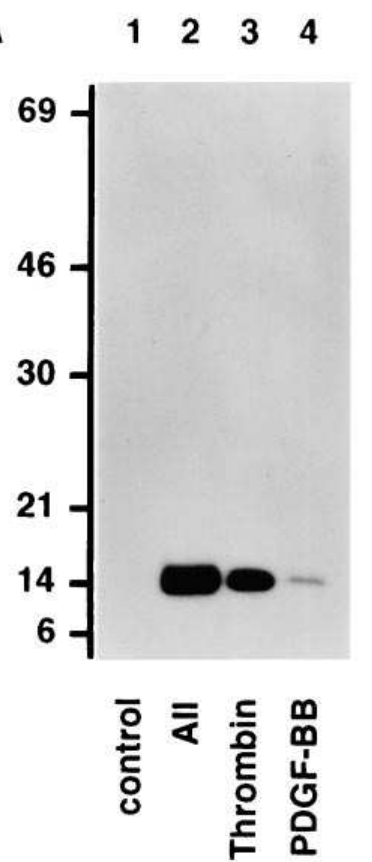

B

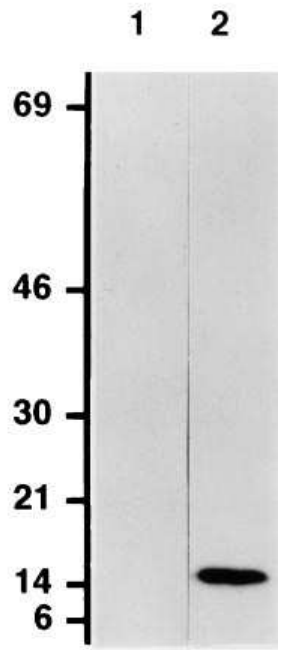

온

Figure 3. Confirmation of activin A protein in conditioned media samples obtained from agonist stimulated RASM cells. Conditioned media samples from agonist stimulated RASM cells were concentrated and analyzed by SDS-PAGE and immunoblot analysis using a monoclonal anti-activin A antibody $(2 \mu \mathrm{g} / \mathrm{ml})$. (A) Quiescent RASM cells were either untreated (lane 1 ) or were stimulated for $8 \mathrm{~h}$ with AII $(1 \mu \mathrm{M}$, lane 2$), \alpha$-thrombin $(10 \mathrm{nM}$, lane 3$)$ or PDGF-BB $(20 \mathrm{ng} /$ $\mathrm{ml}$, lane 4$)$. (B) In a separate experiment, quiescent RASM cells were either untreated (lane 1) or stimulated with PMA (200 nM, lane 2) for $8 \mathrm{~h}$.

lecular weight of the nonreduced protein was consistent with that of the $\beta$ chain dimers $\left(\mathrm{M}_{\mathrm{r}} \sim 26 \mathrm{kD}\right)$ and not with $\alpha \beta$ heterodimers $\left(\mathrm{M}_{\mathrm{r}} \sim 32 \mathrm{kD}\right)$. Electrospray ionization mass spectroscopy was used to confirm the subunit composition of the

nonreduced protein and determined the molecular mass of the nonreduced protein to be $25,932 \pm 2 \mathrm{D}$, identical to that predicted for activin $\mathrm{A}$ ( $\beta \mathrm{A} \beta \mathrm{A}$ homodimer, data not shown).

Induction of activin A expression in RASM cells by the GPCR agonists AII and $\alpha$-thrombin. A monoclonal antibody generated against an activin/inhibin $\beta A$ chain peptide was used to confirm that activin A protein expression was induced in RASM cells by various agonists. Conditioned media samples, obtained from quiescent cells as well as cultures treated for $8 \mathrm{~h}$ with AII, $\alpha$-thrombin, PDGF-BB, or PMA, were analyzed by immunoblotting. Consistent with our previous results (above), we observed no significant expression of the $14 \mathrm{kD}$ activin A protein in unstimulated RASM cells (Fig. $3 A$ ). In contrast, marked increases in RASM cell-secreted activin A protein were observed in response to the GPCR agonists AII and $\alpha$-thrombin, whereas PDGF-BB, a tyrosine kinase receptor agonist, stimulated only a modest increase in activin $\mathrm{A}$ expression (Fig. $3 \mathrm{~A}$ ). Furthermore, in separate experiments, activin A expression was induced by PMA (Fig. $3 B$ ), suggesting that the GPCR agonists stimulate activin A expression through a protein kinase $\mathrm{C}$-dependent mechanism.

Increased expression of activin $\beta A$ subunit $m R N A$ in $A I I-$ stimulated RASM cells. Enhanced expression of activin A from RASM cells after AII exposure could be a result of either increased levels of mRNA translation or proteolytic processing of the prepro form of activin A to its mature form. To determine whether AII stimulated increased levels of activin $\beta A$ mRNA, poly $\mathrm{A}^{+}$mRNA was isolated from RASM cells treated with AII $(1 \mu \mathrm{M})$. Northern blot analysis using the fulllength coding region of activin $\beta A$ cDNA demonstrated an increased level of activin $\beta$ A mRNA within $3 \mathrm{~h}$ of AII stimulation, which peaked at $\sim 6 \mathrm{~h}$ after treatment and returned to basal levels by 18 to $24 \mathrm{~h}$ (Fig. 4). Although the effects of AII on protein translation and posttranslational processing have not been investigated, these results indicate that AII significantly increases the mRNA levels of activin $\beta A$ in RASM cells.

Activin $\beta A$ subunit $m R N A$ is upregulated in the rat carotid injury model. Activin $\beta A$ subunit mRNA expression was also

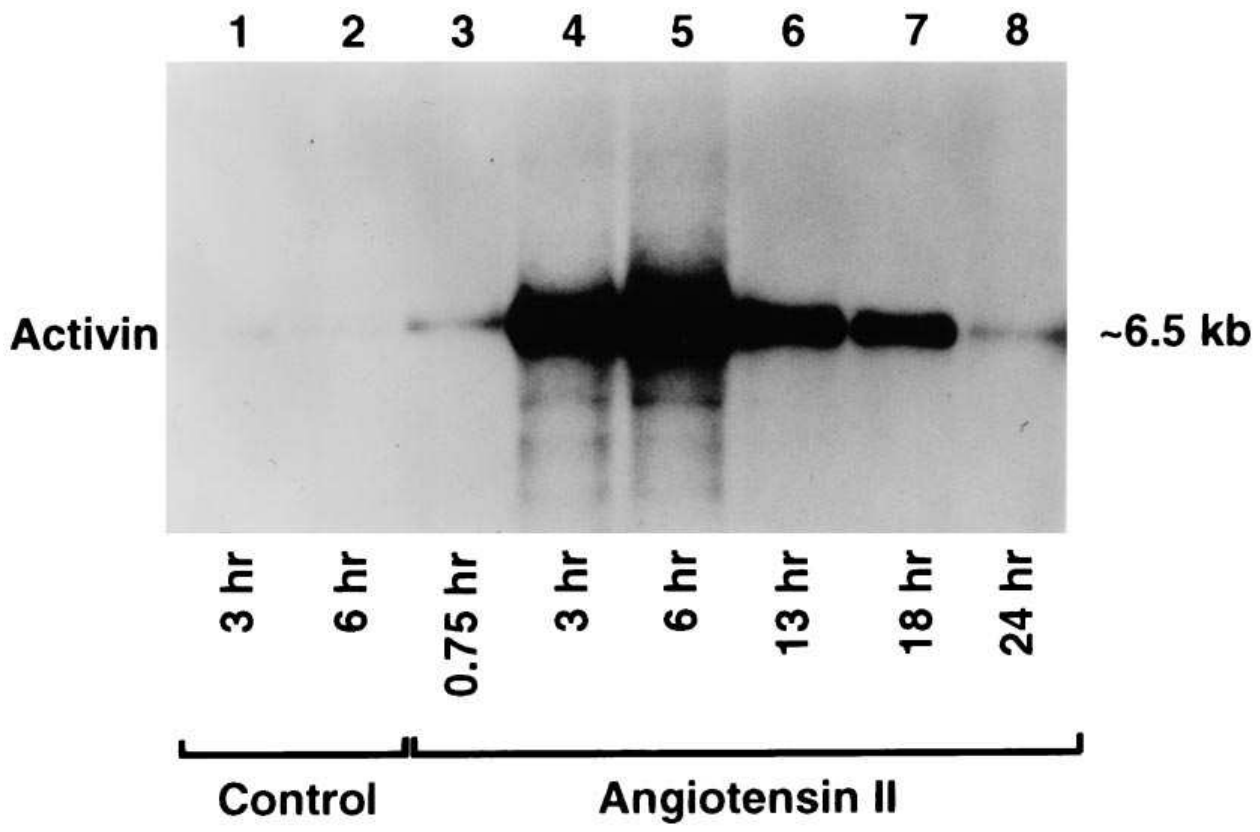

Figure 4. Increased activin A mRNA in cultured RASM cells stimulated with AII. Serum-starved RASM cells were either left untreated or were stimulated with AII $(1 \mu \mathrm{M})$ for the indicated times. Poly $\mathrm{A}^{+}$RNA samples $(2.5 \mu \mathrm{g})$ were electrophoretically resolved in a formaldehyde-denaturing agarose gel and transferred to a nylon membrane. Blots were probed with random primed $\left[{ }^{32} \mathrm{P}\right]$ labeled cDNA containing the full-length coding region of rat activin A and the positively hybridized bands were detected by autoradiography. 
$\begin{array}{llllll}1 & 2 & 3 & 4 & 5 & 6\end{array}$

Activin

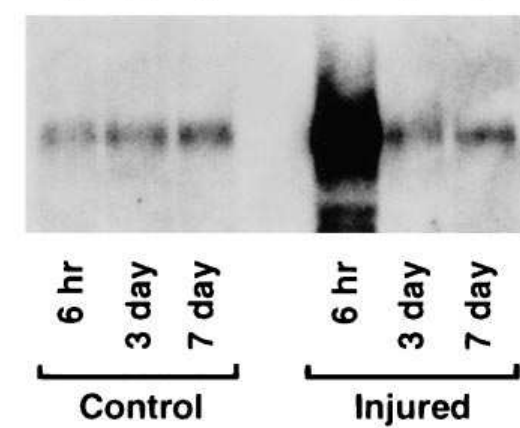

Figure 5. Rapid upregulation of activin A mRNA after balloon injury in rat carotid arteries. Northern blots of total RNA $(\sim 7 \mu \mathrm{g}$ per lane) derived from either control (uninjured, $6 \mathrm{~h}, 3$ or $7 \mathrm{~d}$ ) or ballooninjured (endothelial denudation, $6 \mathrm{~h}, 3$ or $7 \mathrm{~d}$ ) rat carotid arteries were probed with random primed $\left[{ }^{32} \mathrm{P}\right]$ labeled cDNA containing the full-length coding region of rat activin A and the positively hybridized bands were detected by autoradiography.

evaluated after vascular injury in vivo. In these experiments, mRNA was isolated from either control or balloon-injured rat carotid arteries and subjected to Northern blot analysis using a cDNA probe corresponding to the full-length activin $\beta$ A coding region. Low levels of activin mRNA were observed in the uninjured arteries. In contrast, the injured arteries demonstrated a significant increase in activin mRNA $6 \mathrm{~h}$ after injury (Fig. 5). No evidence of increased activin $\beta A$ subunit mRNA expression was seen in the injured carotid arteries after 3 or $6 \mathrm{~d}$ after injury.

Activin A protein expression in balloon-injured rat carotid arteries. Antibodies directed against either smooth muscle cell $\alpha$-actin or activin $\beta$ A chain were used to identify smooth muscle cells and activin A protein expression in control and balloon-injured rat carotid arteries. In uninjured control arteries, $\alpha$-actin positive medial cells expressed low levels of activin A which was also faintly identified in adventitial layers (Fig. 6, $A$ and $B$ ). In contrast, after injury, activin A expression was markedly upregulated. For example, at 2 and $4 \mathrm{~d}$ after injury, increased staining of activin A was observed in both the media and adventitia, as well as the slowly accumulating intimal smooth muscle cells (data not shown). $7 \mathrm{~d}$ after injury, increased amounts of activin A were observed in the adventitia as well as in the smooth muscle cells of the media and neointima (data not shown). By $14 \mathrm{~d}$, activin A staining was most pronounced in neointimal smooth muscle cells, while its staining in the adventitia and media had diminished (Fig. $6 C$ ). By comparison, smooth muscle cell $\alpha$-actin characteristically was detected in both medial and neointimal cells (Fig. $6 \mathrm{D}$ ). Double immunostaining with anti-activin $\mathrm{A}$ (red) and anti- $\alpha$-actin (blue) antibodies revealed many cells that contained both antigens (purple), confirming that neointimal and medial smooth muscle cells simultaneously expressed $\alpha$-actin and activin A (Fig. $6 E$ ). We observed no staining when a normal mouse serum was used as a control (Fig. $6 F$ ).

Activin $A$ potentiates the mitogenic activity of EGF in RASM cells. The mitogenic effects of recombinant activin A were evaluated in quiescent RASM cells. As shown in Fig. $7 A$, when quiescent RASM cells were incubated with recombinant activin A under strictly defined serum-free conditions for either 24 or $48 \mathrm{~h}$, only very minor increases in $\left[{ }^{3} \mathrm{H}\right]$ thymidine incorporation were observed. These small increases in $\left[{ }^{3} \mathrm{H}\right]$ thymidine incorporation were inhibited by recombinant follistatin, a specific activin binding protein. These data indicate that activin A alone, at best, is only a very weak direct mitogen for RASM cells.

Additional experiments were performed to evaluate the effects of activin A in combination with other known mitogens. In these studies, quiescent RASM cells were stimulated with increasing concentrations of PDGF-BB, basic FGF, or EGF in the absence or presence of activin A $(20 \mathrm{ng} / \mathrm{ml})$. As shown in Fig. $7 \mathrm{~B}$, activin A markedly potentiated the mitogenic activity of EGF (two- to fourfold) at each concentration tested, in comparison to the effects of EGF alone. In contrast, activin A did not enhance thymidine incorporation induced by either PDGF-BB or basic FGF (data not shown). The comitogenic effect of activin A with EGF was concentration dependent (Fig. $7 \mathrm{C}$ ) with maximal activity observed at $\sim 30 \mathrm{ng} / \mathrm{ml}(1.2$ $\mathrm{nM})$. Activin A also increased the mitogenic effects of HBEGF on RASM cells (two- to fourfold, data not shown). Similar results also were observed in studies of Swiss 3T3 fibroblasts stimulated with EGF and activin A (data not shown). For example, in these experiments EGF $(10 \mathrm{ng} / \mathrm{ml})$ induced a maximal increase in thymidine incorporation in the Swiss 3 T3 cells that was approximately fourfold above control level. If activin A (20 ng/ml) was added along with EGF this response was increased to ninefold above controls, despite the fact that activin A itself was only weakly mitogenic when added alone (two- to threefold maximal increase in thymidine incorporation).

\section{Discussion}

In previous studies we have employed various immunological and functional methods in an attempt to identify discrete mitogenic factors secreted from vascular smooth muscle cells stimulated with the GPCR agonists AII and $\alpha$-thrombin $(17,18)$. Our results indicated that several known growth factors, including acidic FGF, basic FGF, PDGF, IGF-1, EGF, and TGF- $\beta$, did not contribute significantly to the strong mitogenic activity observed in conditioned media samples obtained from stimulated RASM cells. In this report, we have identified specific polyclonal antibodies, raised against chromatographicallypurified human placental basic FGF, which substantially reduced the strong mitogenic activity of conditioned media from RASM cells treated with AII or $\alpha$-thrombin. Subsequently, these antibodies identified activin A, a member of the TGF- $\beta$ superfamily of polypeptide growth factors, as a distinct protein secreted from GPCR agonist-stimulated RASM cells. Since the amino acid sequences of activin A and basic FGF share little homology, a question arises as to the source of anti-activin immunoreactivity in the basic FGF antiserum. In this regard, activin $\mathrm{A}$ is known to be highly expressed in placenta (35). Thus, it is possible that some of the protein may have copurified with placental basic FGF during antigen preparation and was included as an unintentional immunogen in the preparation of the basic FGF-neutralizing antibodies.

In addition to increased expression observed in quiescent RASM cells in response to GPCR agonists in vitro, intimal activin A protein content was found to be markedly upregulated after rat arterial injury in vivo. These data reinforce previous studies that have identified activin A expression in arterioscle- 

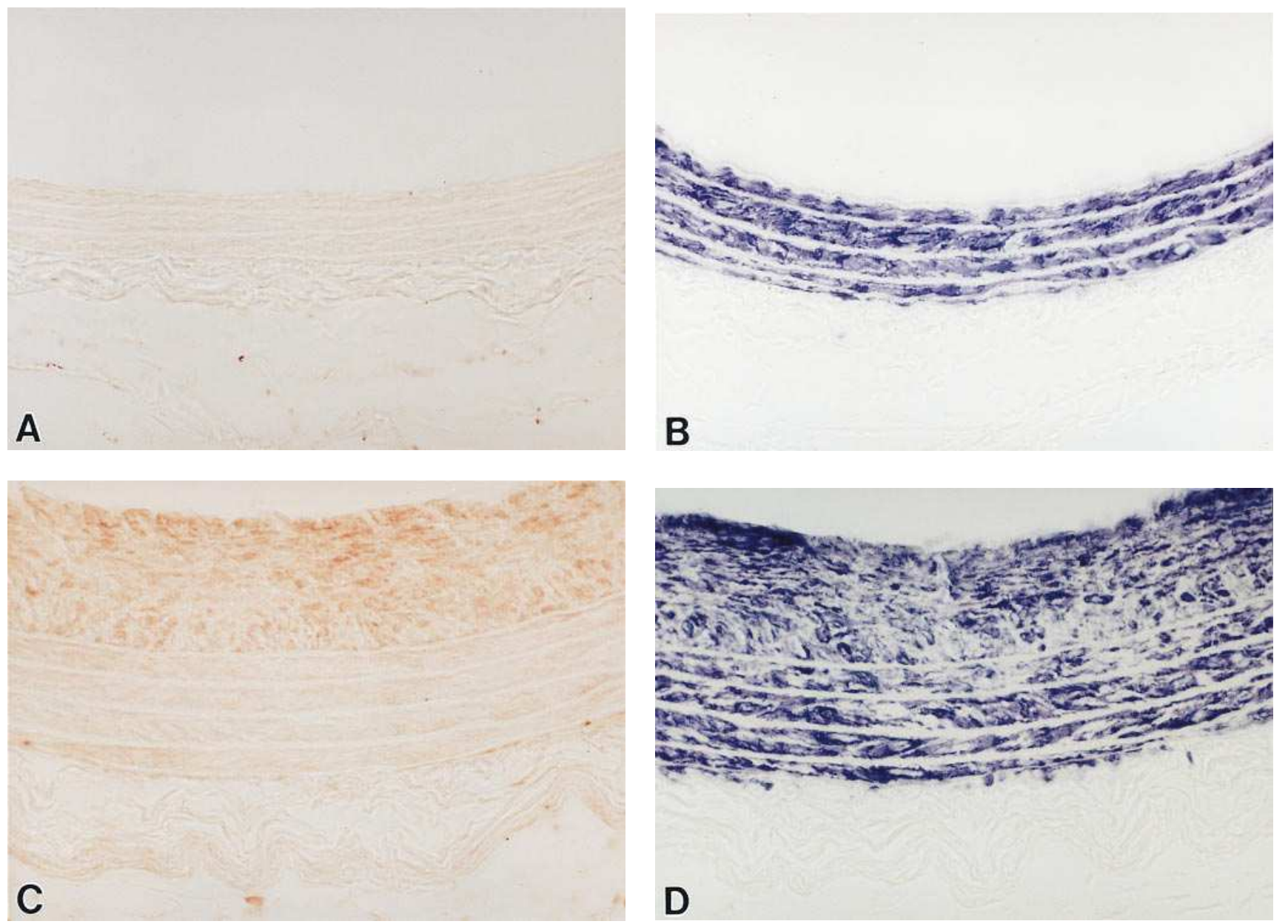

\section{B}
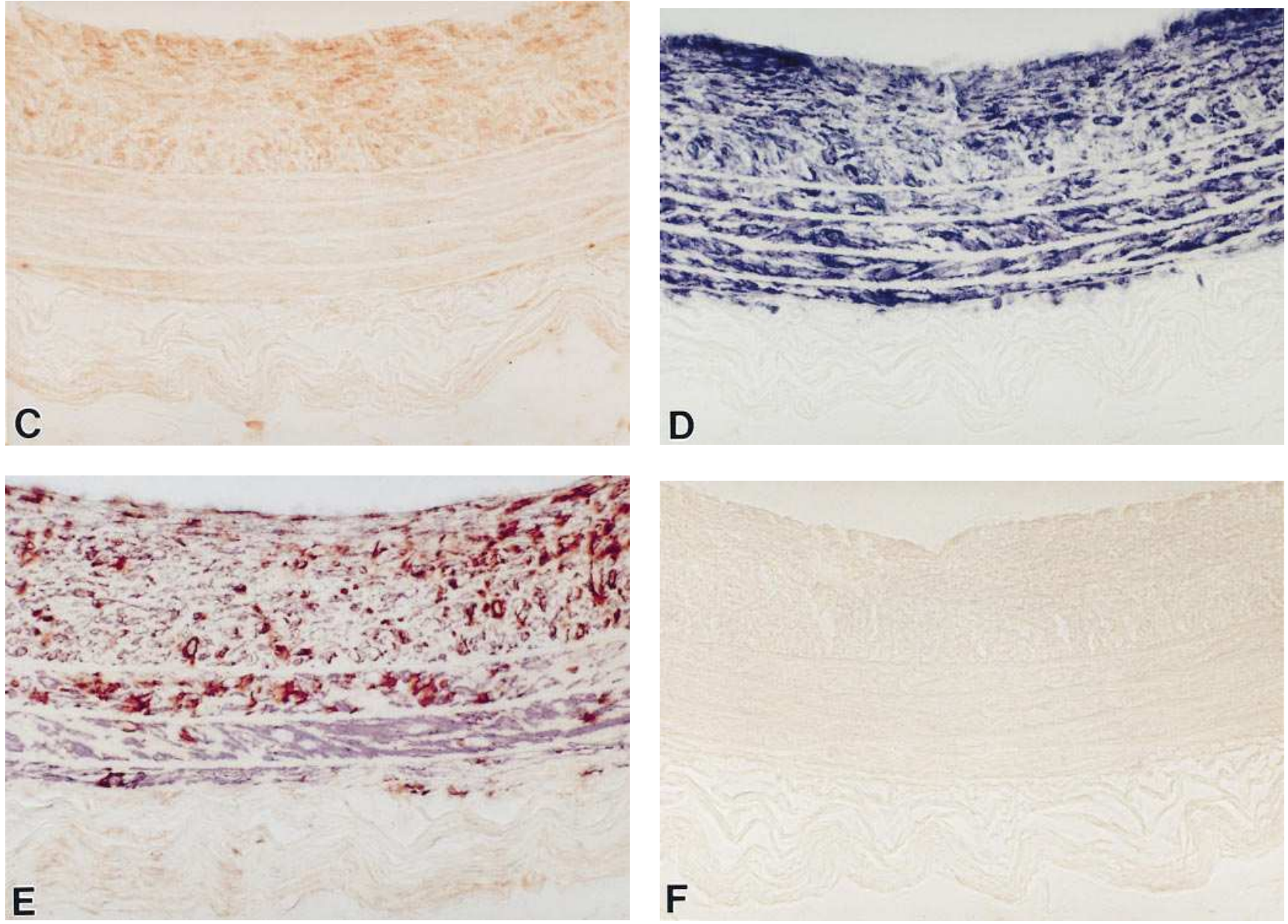

Figure 6. Increased activin A protein expression observed in vivo after balloon injury of rat carotid arteries. Photomicrographs $(\times 40)$ of carotid artery immunohistochemical specimens obtained from uninjured animals $(A$ and $B)$ or $14 \mathrm{~d}$ after balloon injury $(C-F)$. $(A)$ Control artery stained with anti-activin A antibodies (red). (B) Uninjured artery stained anti- $\alpha$-actin antibody (blue) identifies smooth muscle cells in the media. $(C)$ Carotid artery $14 \mathrm{~d}$ following balloon injury. Note that increased anti-activin A antibody staining (red) was localized to neointimal cells as well as a few medial cells. $(D)$ In the $14 \mathrm{~d}$ injured artery, anti- $\alpha$-actin antibodies (blue) identified smooth muscle cells in both the media and neointima. (E) Double antibody immunostaining of postinjury artery using anti- $\alpha$-actin (blue) and anti-activin A (red) identified neointimal and medial smooth muscle cells expressing activin A (purple). (F) Injured carotid artery specimen reacted with normal mouse serum as a control.

rotic lesions from hyperlipidemic rabbits (36) and in the medial layer of human coronary artery samples (37). Taken together, these results imply that activin A plays an important role in the response to vascular injury and accompanying neointimal formation. In addition, these data strongly support the GPCR agonist-stimulated RASM cell system as a relevant model for neointimal proliferation after vascular injury.

Activin exists as disulfide-linked homodimers or het- 
A

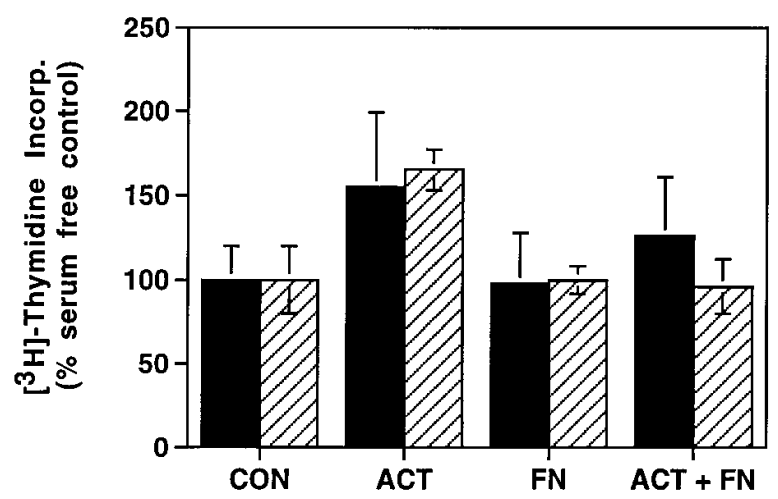

B

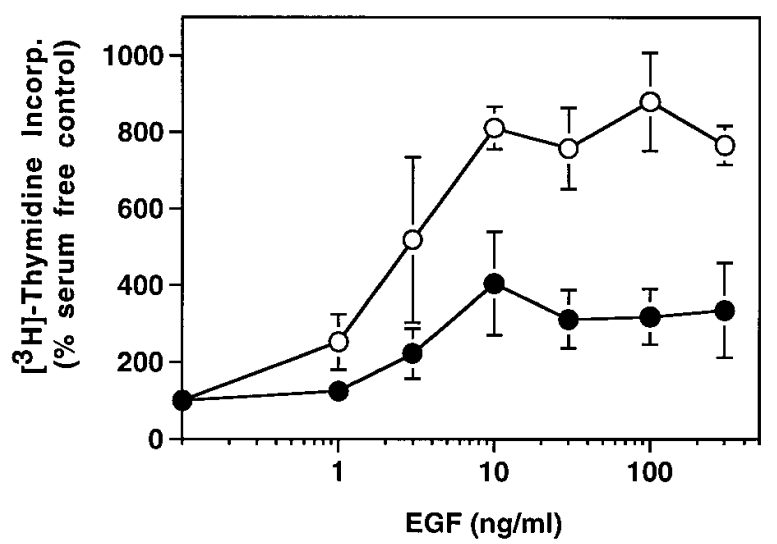

C

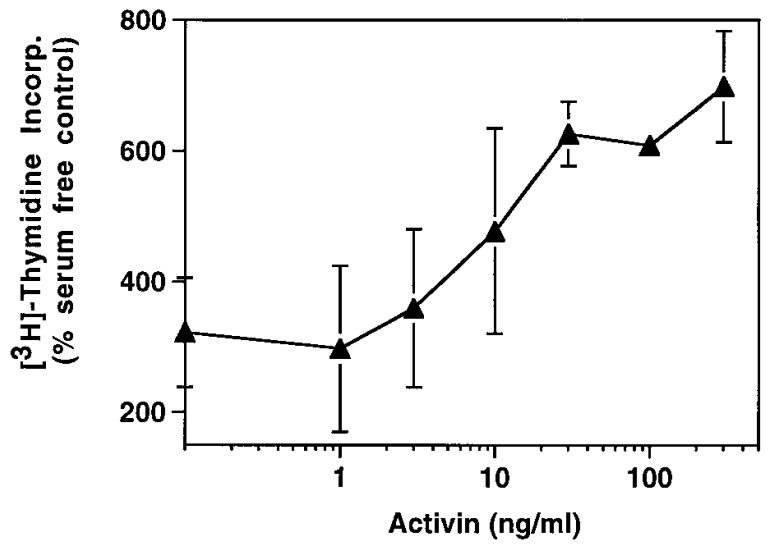

Figure 7. Mitogenic activity of activin A on RASM cells. (A) Quiescent RASM cells were untreated (control, $C O N$ ) or stimulated for $24 \mathrm{~h}$ (solid bars) or $48 \mathrm{~h}$ (hatched bars) with either recombinant activin A $(20 \mathrm{ng} / \mathrm{ml}, A C T)$ or recombinant follistatin $(500 \mathrm{ng} / \mathrm{ml}, F N)$, alone or in combination as indicated. $(B)$ Quiescent RASM cells were treated for $24 \mathrm{~h}$ with increasing concentrations of EGF as indicated in the absence (closed circles) or presence (open circles) of activin A ( 20 $\mathrm{ng} / \mathrm{ml}$ ). (C) Quiescent RASM cells were treated for $24 \mathrm{~h}$ with increasing concentrations of activin A in the presence of EGF ( $3 \mathrm{ng} / \mathrm{ml})$. Results are expressed as $\left[{ }^{3} \mathrm{H}\right]$ thymidine incorporation of treated cells as a percentage of the serum-free control levels. Values shown are the mean \pm SEM from experiments performed either two $(A)$ or three times $(B$ and $C$ ) with triplicate samples in each experiment.

erodimers of the inhibin $\beta A$ and/or $\beta B$ polypeptide chains respectively $(33,34)$. These proteins were originally identified by their ability to stimulate the secretion of follicle stimulating hormone from anterior pituitary cells. Activin A also interacts with other cell types, for example, it has been identified as an erythroid differentiation factor (38), and a potent inducer of mesoderm in Xenopus laevis $(39,40)$. The mitogenic properties of activin A have also been described for cultured vascular smooth muscle cells (41) as well as fibroblasts (42). Activin A has been shown to induce DNA synthesis in porcine thyroid cells (43), MC3T3-E1 osteoblasts (44), and preleptotene spermatocytes (45). In this study we found that activin A, although only weakly mitogenic when added alone to RASM cells, significantly potentiated the levels of DNA synthesis stimulated by EGF or HB-EGF. Although the exact mechanism for this effect awaits further investigation, it could be due to induction of EGF receptor expression. Furthermore, since EGF $(46,47)$ and HB-EGF $(48,49)$ have been implicated previously in vascular remodeling that accompanies atherogenesis and/or sustained hypertension, our results support a modulatory role for activin $\mathrm{A}$ in these processes.

Additional biological effects of activin in the injured artery wall also are possible. For example, activin A has been shown to increase monocyte migration (50), as well as induce apoptosis in certain myeloma cell lines (51). Recent studies have also demonstrated that activin inhibits the growth of rat thymocytes (52), hepatocytes (53), and human or bovine endothelial cells (54). Thus, after vascular injury, activin A secreted from vascular smooth muscle cells might act upon adventitial fibroblasts, smooth muscle cells, and/or monocytes to coordinate arterial repair. Furthermore, since activin A inhibits proliferation of vascular endothelial cells, it is possible that excessive activin expression in artery wall may delay re-endothelialization at the site of vascular injury. Additionally, activin A may be involved in the stimulation of vascular smooth muscle cell apoptosis reported after vascular injury $(55,56)$.

The TGF- $\beta$ superfamily is comprised of potent growth factors implicated previously in vascular diseases $(57,58)$. For example, a recent study demonstrated that neutralizing antibodies directed against recombinant TGF- $\beta_{1}$ could suppress neointimal formation in the rat carotid-injury model (59). Additionally, other TGF- $\beta$ isoforms are well-characterized stimuli for extracellular matrix proteins in connective tissue cells (60-62). Thus, the functions of activin A in vascular injury may include the direct and indirect stimulation of tissue remodeling. In support of this concept, recent studies have identified increased activin A expression in interstitial pulmonary fibrotic lesions (63) and skin wounds (64). These findings indicate that activin A may be important in both vascular and superficial wound repair. However, additional studies using activin A neutralizing antibodies will be required to determine the full spectrum of cellular events elicited by activin $\mathrm{A}$ in the vasculature and its role in vascular injury.

\section{Acknowledgments}

We thank Dr. Thomas Meek for helpful discussions and critical reading of the manuscript. We also gratefully acknowledge Tonya Jenkins-West for expert technical assistance and Dr. Kristine M. Swiderek (Director, City of Hope Microsequencing and Mass Spectrometry Core Facility at the Beckman Research Institute, Duarte, CA) for amino acid sequencing.

\section{References}

1. Scott-Burden, T., T.J. Resink, A.W.A. Hahn, and P.M. Vanhoutte. 1991. Induction of endothelin secretion by angiotensin II: effects on growth and syn- 
thetic activity of vascular smooth muscle cells. J. Cardiovasc. Pharmacol. 17: S96-S100.

2. Powell, J.S., M. Rouge, R.K.M. Müller, and H.R. Baumgartner. 1991. Cilazapril suppresses myointimal proliferation after vascular injury: effects on growth factor induction in vascular smooth muscle cells. Basic Res. Cardiol. 86(Suppl.):65-74.

3. Weber, H., M.L. Webb, R. Serafino, D.S. Taylor, S. Moreland, J. Norman, and C.J. Molloy. 1994. Endothelin-1 and angiotensin-II stimulate delayed mitogenesis in cultured rat aortic smooth muscle cells: evidence for common signaling mechanisms. Mol. Endocrinol. 8:148-158.

4. Huang, C.-L., and H. E. Ives. 1987. Growth inhibition by protein kinase C late in mitogenesis. Nature (Lond.). 329:849-850.

5. Herbert, J.M., I. Lamarch, and F. Dol. 1992. Induction of vascular smooth muscle cell growth by selective activation of the thrombin receptor: effect of heparin. FEBS Lett. 301:155-158.

6. McNamara, C.A., I.J. Sarembock, L.W. Gimple, J.W. Fenton II, S.R. Coughlin, and G.K. Owens. 1993. Thrombin stimulates proliferation of cultured rat aortic smooth muscle cells by a proteolytically activated receptor. J. Clin. Invest. $91: 94-98$.

7. Scott-Burden, T., A.W.A. Hahn, T.J. Resink, and F.R. Buhler. 1990. Modulation of extracellular matrix by angiotensin II: stimulated glycoconjugate synthesis and growth in vascular smooth muscle cells. J. Cardiovasc. Pharmacol. 16:S36-S41.

8. Sharifi, B.G., D.W. LaFleur, C.J. Pirola, J.S. Forrester, and J.A. Fagin. 1992. Angiotensin II regulates tenascin gene expression in vascular smooth muscle cells. J. Biol. Chem. 267:23910-23915.

9. Bailey, W.L., D.W. LaFleur, J.S. Forrester, J.A. Fagin, and B.G. Sharifi. 1994. Stimulation of rat vascular smooth muscle cell glycosaminoglycan production by angiotensin II. Atherosclerosis. 111:55-64.

10. Carney, D.H., R. Mann, W.R. Redin, S.D. Pernia, D. Berry, J.P. Heggers, P.G. Hayward, M.C. Robson, J. Christie, C. Annable, et al. 1992. Enhancement of incisional wound healing and neovascularization in normal rats by thrombin and synthetic thrombin receptor-activating peptides. J. Clin. Invest. 89:1469-1477.

11. Sung, C.-P., A.J. Arleth, B.L. Storer, and E.H. Ohlstein. 1994. Angiotensin type 1 receptors mediate smooth muscle proliferation and endothelin biosynthesis in rat vascular smooth muscle. J. Pharmacol. Exp. Ther. 271:429437.

12. Coughlin, S. 1994. Thrombin receptor function and cardiovascular disease. Trends Cardiovasc. Med. 4:77-83.

13. Rogers, T.B., and A.J. Lokuta. 1994. Angiotensin II signal transduction pathways in the cardiovascular system. Trends Cardiovasc. Med. 4:110-116.

14. Berk, B.C., M.B. Taubman, E.J. Cragoe, Jr., J.W. Fenton II, and K.K. Griendling. 1990. Thrombin signal transduction mechanisms in rat vascular smooth muscle cells: calcium and protein kinase C-dependent and -independent pathways. J. Biol. Chem. 265:17334-17340.

15. Duff, J.L., M.B. Marrero, W.G. Paxton, B. Schieffer, K.E. Bernstein, and B.C. Berk. 1995. Angiotensin II signal transduction and the mitogen-activated protein kinase pathway. Cardiovasc. Res. 30:530-536.

16. Van Obberghen-Schilling, E., and J. Pouyssegur. 1993. Signaling pathways of the thrombin receptor. Thromb. Haemostasis. 70:163-167.

17. Weber, H., D.S. Taylor, and C.J. Molloy. 1994. Angiotensin II induces delayed mitogenesis and cellular proliferation in rat aortic smooth muscle cells: correlation with the expression of specific endogenous growth factors and reversal by suramin. J. Clin. Invest. 93:788-798.

18. Molloy, C.J., J.E. Pawlowski, D.S. Taylor, C.E. Turner, H. Weber, M. Peluso, and S.M. Seiler. 1996. Thrombin receptor activation elicits rapid protein tyrosine phosphorylation and stimulation of the raf-1/MAP kinase pathway preceding delayed mitogenesis in cultured rat aortic smooth muscle cells: evidence for an obligate autocrine mechanism promoting cell proliferation induced by G protein-coupled receptor agonists. J. Clin. Invest. 97:1173-1183.

19. Naftilan, A.J., R.E. Pratt, and V.J. Dzau. 1989. Induction of plateletderived growth factor A-chain and c-myc gene expressions by angiotensin II in cultured rat vascular smooth muscle cells. J. Clin. Invest. 83:1419-1424.

20. Stouffer, G.A., I.J. Sarembock, C.A. McNamara, L.W. Gimple, and G.K. Owens. 1993. Thrombin-induced mitogenesis of vascular SMC is partially mediated by autocrine production of PDGF-AA. Am. J. Physiol. 265:C806C811.

21. Kanthou, C., O. Benzakour, G. Patel, J. Deadman, V.V. Kakkar, and F. Lupu. 1995. Thrombin receptor activating peptide (TRAP) stimulates mitogenesis, c-fos and PDGF-A gene expression in human vascular smooth muscle cells. Thromb. Haemostasis. 74:1340-1347.

22. Weiss, R.H., and M. Maduri. 1993. The mitogenic effect of thrombin in vascular smooth muscle cells is largely due to basic fibroblast growth factor. $J$. Biol. Chem. 268:5724-5727.

23. Itoh, H., M. Mukoyama, R.E. Pratt, G.H. Gibbons, and V.J. Dzau. 1993. Multiple autocrine growth factors modulate vascular smooth muscle cell growth response to angiotensin II. J. Clin. Invest. 91:2268-2274.

24. Delafontaine, P., A. Anwar, H. Lou, and L. Ku. 1996. G-protein coupled and tyrosine kinase receptors: evidence that activation of the insulin-like growth factor 1 receptor is required for thrombin-induced mitogenesis of rat aortic smooth muscle cells. J. Clin. Invest. 97:139-145.
25. Serruys, P.W., H.J.-P.R. Herrman, R. Simon, W. Rutsch, C. Bode, G.-J. Laarman, R. van Dijk, A.A. van den Bos, V.A.W.M. Umans, K.A.A. Fox, et al. 1995. A comparison of hirudin with heparin in the prevention of restenosis after coronary angioplasty. N. Engl. J. Med. 333:757-763.

26. Heyndrickx, G.R. 1993. Angiotensin-converting enzyme inhibitor in a human model of restenosis. Basic Res. Cardiol. 88 (Suppl.):169-182.

27. Giachelli, C., N. Bae, D. Lombardi, M. Majesky, and S. Schwartz. 1991. Molecular cloning and characterization of 2B7, a rat mRNA which distinguishes smooth muscle cell phenotypes in vitro and is identical to osteopontin (secreted phosphoprotein I, 2aR). Biochem. Biophys. Res. Commun. 177:867873.

28. Molloy, C.J., D.S. Taylor, and H. Weber. 1993. Angiotensin II stimulation of rapid protein tyrosine phosphorylation and protein kinase activation in rat aortic smooth muscle cells. J. Biol. Chem. 268:7338-7345.

29. Chomczynski, P., and N. Sacchi. 1987. Single-step method of RNA isolation by acid guanidinium thiocyanate-phenol-chloroform extraction. Anal. Biochem. 162:156-159.

30. Esch, F.S., S. Shimasaki, K. Cooksey, M. Mercado, A.J. Mason, S.-Y Ying, N. Ueno, and N. Ling. 1987. Complementary deoxyribonucleic acid (cDNA) cloning and DNA sequence analysis of rat ovarian inhibins. Mol. Endocrinol. 1:388-396.

31. Woodruff, T.K., H. Meunier, P.B.C. Jones, A.J.W. Hsueh, and K.E. Mayo. 1987. Rat Inhibin: molecular cloning of $\alpha$ - and $\beta$-subunit complementary deoxyribonucleic acids and expression in the ovary. Mol. Endocrinol. 1:561568.

32. Ferrer, P., M. Valentine, T. Jenkins-West, H. Weber, N.L. Goller, S.K. Durham, C.J. Molloy, and S. Moreland. 1995. Orally active endothelin receptor antagonist BMS-182874 suppresses neointimal development in balloon-injured rat carotid arteries. J. Cardiovasc. Pharmacol. 26:908-915.

33. Vale, W., A. Hsueh, C. Rivier, and J. Yu. 1990. The inhibin/activin family of hormones and growth factors. In Peptide Growth Factors and Their Receptors II. M.B. Sporn and A.B. Roberts, editors. Springer-Verlag New York Inc., New York. 95:211-248.

34. Ying, S.Y. 1988. Inhibins, activins, and follistatins: gonadal proteins modulating the secretion of follicle-stimulating hormone. Endocr. Rev. 9:267293.

35. Petraglia, F., P.E. Sawchenko, A.T.W. Lim, G. Rivier, and W. Vale. 1987. Localization, secretion, and action of inhibin in human placenta. Science (Wash. DC). 237:187-189.

36. Inoue, S., A. Orimo, T. Hosoi, A. Ikegami, K. Kozaki, Y. Ouchi, S. Nomura, M. Muramatsu, and H. Orimo. 1994. Demonstration of activin-A in arteriosclerotic lesions. Biochem. Biophys. Res. Commun. 205:441-448.

37. Kozaki, K., Y. Ouchi, M. Akishita, M. Eto, K. Toba, K. Nagano, S. Inoue, M. Ishikawa, M. Hashimoto, T. Kodama, et al. 1995. Demonstration of the expression of activin-A and follistatin in atherosclerotic lesions: their role in foam cell formation of THP-1 macrophage in vitro. Circulation. 92:I-160.

38. Yu, J., L. Shao, V. Lemas, A.L. Yu, J. Vaughn, J. Rivier, and W. Vale. 1987. Importance of FSH-releasing protein and inhibin in erythrodifferentiation. Nature (Lond.). 330:765-767.

39. Smith, J.C., B.M.J. Price, K. van Nimmen, and D. Huylebroeck. 1990. Identification of a potent Xenopus mesoderm-inducing factor as a homologue of activin A. Nature (Lond.). 345:729-731.

40. van den Eijnden-van Raaij, A.J.M., E.J.J. van Zoelen, K. van Nimen, C.H. Koster, G.T. Snoek, A.J. Durston, and D. Huylebroeck. 1990. Activin-like factor from a Xenopus laevis cell line responsible for mesoderm induction. $\mathrm{Na}$ ture (Lond.). 345:732-735.

41. Kojima, I., H. Mogami, N. Kawamura, H. Yasuda, and H. Shibata. 1993. Modulation of growth of vascular smooth muscle cells by activin A. Exp. Cell Res. 206:152-156.

42. Sakurai, T., Y. Abe, Y. Kasuya, N. Takuwa, R. Shiba, T. Yamashita, T. Endo, and K. Goto. 1994. Activin A stimulates mitogenesis in Swiss 3 T3 fibroblasts without activation of mitogen-activated protein kinases. J. Biol. Chem. 269:14118-14122.

43. Kotajima, A., Y. Miyamoto, M. Tsuruo, M. Kosaka, and S. Saito. 1995. Effects of activin A on deoxyribonucleic acid synthesis, iodine metabolism, and cyclic adenosine monophosphate accumulation in porcine thyroid cells. Endocrinology. 136:1214-1218.

44. Hashimoto, M., A. Shoda, S. Inoue, R. Yamada, T. Kondo, T. Sakurai, N. Ueno, and M. Muramatsu. 1992. Functional regulation of osteoblastic cells by the interaction of activin-A with follistatin. J. Biol. Chem. 267:4999-5004.

45. Hakovirta, H., A. Kaipia, O. Söder, and M. Parvinen. 1993. Effects of activin-A, inhibin- $\mathrm{A}$, and transforming growth factor- $\beta 1$ on stage-specific deoxyribonucleic acid synthesis during rat seminiferous epithelial cycle. Endocrinology. 133:1664-1668.

46. Sambhi, M.P., N. Swaminathan, H. Wang, and H. Rong. 1992. Increased EGF binding and EGFR mRNA expression in rat aorta with chronic administration of pressor angiotensin II. Biochem. Med. Metab. Biol. 48:8-18.

47. Rossi, M.J., N. Chegini, and B.J. Masterson. 1992. Presence of epidermal growth factor, platelet-derived growth factor, and their receptors in human myometrial tissue and smooth muscle cells: their action in smooth muscle cells in vitro. Endocrinology. 130:1716-1727.

48. Temizer, D.H., M. Yoshizumi, M.A. Perrella, E.E. Susanni, T. Querter- 
mous, and M.-E. Lee. 1992. Induction of heparin-binding EGF-like growth factor mRNA by phorbol ester and angiotensin II in rat aortic smooth muscle cells. J. Biol. Chem. 267:24892-24896.

49. Miyagawa, J., S. Higashiyama, S. Kawata, Y. Inui, S. Tamura, K. Yamamoto, M. Nishida, T. Nakamura, S. Yamashita, Y. Matsuzawa, and N. Taniguchi. 1995. Localization of heparin-binding EGF-like growth factor in the smooth muscle cells and macrophages of human atherosclerotic plaques. $J$. Clin. Invest. 95:404-411.

50. Petraglia, F., P. Sacerdote, A. Cossarizza, S. Angioni, A.D. Genazzani, C. Franceschi, M. Muscettola, and G. Grasso. 1991. Inhibin and activin modulate human monocyte chemotaxis and lymphocyte interferon- $\gamma$ production. $J$. Clin. Endocrinol. Metab. 72:496-502.

51. Nishihara, T., N. Okahashi, and N. Ueda. 1993. Activin A induces apoptotic cell death. Biochem. Biophys. Res. Commun. 197:985-991.

52. Hedger, M.P., A.E. Drummond, D.M. Robertson, G.P. Risbridger, and D.M. de Kretser. 1989. Inhibin and activin regulate $\left[{ }^{3} \mathrm{H}\right]$ thymidine uptake by rat thymocytes and 3T3 cells in vitro. Mol. Cell. Endocrinol. 61:133-138.

53. Yasuda, H., T. Mine, H. Shibata, Y. Eto, Y. Hasegawa, T. Takeuchi, S. Asano, and I. Kojima. 1993. Activin A: an autocrine inhibitor of initiation of DNA synthesis in rat hepatocytes. J. Clin. Invest. 92:1491-1496.

54. McCarthy, S.A., and R. Bicknell. 1993. Inhibition of vascular endothelial cell growth by activin-A. J. Biol. Chem. 268:23066-23071.

55. Bennett, M.R., G.I. Evan, and S.M. Schwartz. 1995. Apoptosis of rat vascular smooth muscle cells is regulated by p53-dependent and -independent pathways. Circ. Res. 77:266-273.

56. Bennett, M.R., G.I. Evan, and S.M. Schwartz. 1995. Apoptosis of human coronary vascular smooth muscle cells derived from normal vessels and coronary atherosclerotic plaques. J. Clin. Invest. 95:2266-2274.

57. Border, W.A., and E. Ruoslahti. 1992. Transforming growth factor- $\beta$ in disease: the dark side of tissue repair. J. Clin. Invest. 90:1-7.

58. Roberts, A.B., B.K. McCune, and M.B. Sporn. 1992. TGF- $\beta$ : regulation of extracellular matrix. Kidney Int. 41:557-559.

59. Wolf, Y.G., L.M. Rasmussen, and E. Ruoslahti. 1994. Antibodies against transforming growth factor- $\beta 1$ suppress intimal hyperplasia in a rat model. J. Clin. Invest. 93:1172-1178.

60. Massagué, J. 1987. The TGF- $\beta$ family of growth and differentiation factors. Cell. 49:437-438.

61. Roberts, A.B., M.B. Sporn, R.K. Assoian, J.M. Smith, N.S. Roche, L.M. Wakefield, U.I. Heine, L.A. Liotta, V. Falanga, J.H. Kehrl, and A.S. Fauci. 1986. Transforming growth factor $\beta$ : rapid induction of fibrosis and angiogenesis in vivo and stimulation of collagen formation in vitro. Proc. Natl. Acad. Sci. USA. 83:4167-4171.

62. Roberts, A.B. 1995. Transforming growth factor- $\beta$ : activity and efficacy in animal models of wound healing. Wound Repair Regen. 3:408-418.

63. Matsuse, T., A. Ikegami, E. Ohga, T. Hosoi, T. Ika, K. Kida, F. Masashi, S. Inoue, T. Nagase, Y. Ouchi, and Y. Fukuchi. 1996. Expression of immunoreactive activin A protein in remodeling lesions associated with interstitial pulmonary fibrosis. Am. J. Pathol. 148:707-713.

64. Hübner, G., Q. Hu, H. Smola, and S. Werner. 1996. Strong induction of activin expression after injury suggests an important role of activin in wound repair. Dev. Biol. 173:490-498. 